\title{
Oyuncak Seçiminde Ebeveynlerin Cinsiyet Algısının Satın Alma Niyeti Üzerindeki Etkisi ${ }^{1}$
}

\author{
DOI: $10.26466 /$ opus.891026 \\ * \\ Öznur Özer * - Deniz Akgül ** \\ * Yüksek Lisans Öğrencisi, Kırşehir Ahi Evran Üniversitesi, Kırşehir/Türkiye \\ E-Posta: oznurozerr@hotmail.com \\ ORCID: $\underline{0000-0002-5705-8575}$ \\ ${ }^{* *}$ Dr. Öğr. Üyesi, Kırşehir Ahi Evran Üniversitesi, Kırşehir/Türkiye \\ E-Posta: deniz.akgul@ahievran.edu.tr \\ ORCID: $\underline{0000-0002-5143-7267}$
}

Öz

Oyuncak, bir oyun nesnesi olmakla beraber aynı zamanda toplumsal cinsiyet rollerinin yansıtıldı̆̆ toplumsal normlardan izler taşıyan bir ürün mahiyetindedir. Toplumsal algı ebeveynlerin tüketim pratiklerini de etkileyerek oyuncak konusundaki satın alma davranışarına yön vermektedir. Bu nedenle oyuncak seçiminin sosyolojik bir temelde de değerlendirilmesi gerekmektedir. Bu araştırmada, ebeveynlerin çocuklar için oyuncak alışverişi konusunda toplumsal cinsiyete dair tutumları değerlendirilecek ve bu tutumlarm tüketimlerine yansıması incelenecektir. Çalışmanın amacı; oyuncaklarda firmaların kullanmış oldukları renk şekil gibi cinsiyet göstergelerine karşı ebeveynlerin tutumların incelemek ve bu tutumlar üzerinde etkisi olan toplumsal cinsiyet algısını ve kültürel kodları belirlemektir. Veri toplama aracı olarak cinsiyet rolleri tutum ölçeği, satın alma niyeti ölçeği kullanılmıştır. Anket 0-6 yaş grubu arasında çocuğu olan kişilere online olarak uygulanmıştır. Çalışmanın veri analizi SPSS programı ile yapılmış ve toplumsal cinsiyet algısının oyuncak satın alma niyeti üzerinde etkili olduğu belirlenmiştir. Ebeveynlerin oyuncak seçiminde cinsiyet alguları demografik özelliklerine göre anlaml farklılık göstermektedir. Ebeveynlerin satın alma niyetlerinin demografik özelliklerine ve eğitim durumlarına göre anlaml farklılık gösterdiği belirlenmiştir.

Anahtar Kelimeler: Oyuncak seçimi, Cinsiyet algısı, Satın alma niyeti

\footnotetext{
${ }^{1}$ Bu çalış̧ma Kırşehir Ahi Evran Üniversitesi Sosyal Bilimler Enstitüsü bünyesinde halen yürütülmekte olan aynı isimli tez çalışmasının bir bölümünden türetilmiş ve özet bildiri olarak Ocak 2021 Pearson Journal International Conference on Social Sciences \& Humanities'de sunulmuştur.
} 
ISSN:2528-9527

E-ISSN : 2528-9535

YIl Year: 11

Cilt Volume: 17

Sayı Issue :38

Uluslararası Toplum Araştırmaları Dergisi

International Journal of Society Researches

Hairan June 2021

Makalenin Geliş Tarihi Received Date: 04/03/2021

Makalenin Kabul Tarihi Accepted Date: 21/04/2021

\title{
The Effect of Parents' Gender Perception in Toy Selection on Purchasing Choices
}

*

\begin{abstract}
The toy is an object of play, but at the same time, it is a product that reflects gender roles and carries traces from social norms. Social perception, influences and directs consumption practices. For this reason, toy choice should be evaluated on a sociological basis. In this study, parents' gender attitudes towards toy shopping for their children will be evaluated and reflection of these attitudes on their consumption will be examined. The aim of the study, to analyze parents' attitudes towards gender indicators such as color and shape used by companies in toys and to determine gender perception and cultural codes that have an impact on these attitudes. Data collection scale, Gender roles attitude scale and purchase intention scale were used. The survey was applied online to people who have children between the ages of 0-6. The data analysis of this study was made with the SPSS program and it was determined that gender perception an effect on the toy purchase intention. Gender perceptions of parents' choice of toys differ significantly according to their demographics. It was determined that parents ' purchasing intentions differ significantly according to their demographics and educational status.
\end{abstract}

Keywords: Choosing toys, Sex perception, Intention to buy 


\section{Giriş}

Oyunun temel aracı olan oyuncak, bir oyun nesnesi olmakla birlikte çocuklar için hayal dünyalarını geliştiren, birtakım motor becerileri kazandıran, zihinsel ve sosyal açıdan katkı sağlayan önemli bir araç niteliğindedir. Oyun ve oyuncak, çocuğun fiziksel, duygusal, zihinsel, sosyal gelişiminde önemli bir eğitici ve öğreticidir. Çocuğun hayata bakış açısının şekillenmesinde, toplumsal cinsiyet rollerini zihninde konumlandırarak içselleştirmesinde okul öncesi dönem kritik ve çok önemli bir evredir. Bu evrede, oyun ve oyuncak çocuğun dünya ile arasındaki köprü misali önemli bir etkiye sahiptir. Bu yönüyle çocuk için oyun ve oyuncak, hayatın provası gibidir. Oyun ile gerçek dünyanın minyatür halini inşa ederek, küçük bir alanda kendi gerçekliğini yaratır. Bu alanda, kendini de konumlandırarak roller biçmekte ve kimliğini kazanmaktadır.

Çocuğun oynayacağı oyuncağın seçimi konusunda, ebeveynler bazen onları özgür bırakırken, bazen de çocuğun tercih sürecine katılması ile onlarla birlikte karar verebilirler. Bazı durumlarda ise ebeveynler salt kendi tercihleri ile çocuğu daha edilgen şekilde konumlandırarak bir seçim yapabilirler. Ebeveynler bu süreçte önemli rol oynamaktadırlar ve çocuklarına oyuncak satın alma sürecinde birçok değişkeni dikkate alarak seçim yapmaktadırlar. Bu değişkenlerden biri, çocuğun cinsiyetidir ve ebeveynlerin oyuncak seçiminde kayda değer şekilde önem teşkil etmektedir. Oyuncak seçimi yaparken; oyuncağın rengi, türü, fonksiyonu gibi faktörleri de dikkate almaktadırlar. Çocuğun oyuncaklarının çoğunluğu, renk ve tür açısından "toplumsal cinsiyetine uygun" olarak seçilmektedir. Bu nedenle, ebeveynlerin oyuncak seçimi; sosyolojik ve psikolojik eksende değerlendirilmesi gereken çok boyutlu bir nitelik arz etmektedir. Bireyler tüketim yaparken içinde bulundukları toplumsal normlardan ve psikolojik durumlardan bağımsız değillerdir. Bu nedenle "tüketim kültürü", "tüketici psikolojisi" gibi nitelendirmeler ortaya çkmıştır. Bu açıdan, ebeveynlerin çocukları için oyuncak tercihinde cinsiyet açısından hangi kültürel kodlarla düşündüklerini ve hangi psikolojik motivasyonla davrandıklarını anlamak ve analiz etmek önemlidir.

Bu çalışmada, ebeveynlerin çocukları için yaptıkları oyuncak alışverişlerinde, toplumsal cinsiyet algısının etkilerini araştırmak amaçlanmaktadır. Oyuncaklarda, firmaların kullanmış oldukları renk şekil gibi cinsiyet göstergelerine, tüketici olarak ebeveynlerin tutumları ve bu tutumların satın alma 
kararı üzerindeki etkileri ölçmek amaçlanmıştır. Ebeveynlerin çocukları için oyuncak alışverişine ilişkin cinsiyetçi tutumları değerlendirilmiş ve bu tutumların tüketimlerine yansıması incelenmiştir. Temel amaç; oyuncaklarda firmaların kullanmış oldukları renk, şekil gibi cinsiyet göstergelerine karşı alışveriş esnasında ailelerin tutumları ve bu tutumlar üzerinde etkisi olan değişkenleri incelemektir. Aynı zamanda cinsiyetçi tutumların ebeveynlerin sosyo-kültürel, sosyo-ekonomik durumlarına göre değişkenliğini belirleyerek bir analiz yapmak amaçlanmaktadır.

\section{Literatür ve Kavramsal Çerçeve}

Küçük çocuklar, cinsiyet anlayışlarını okul öncesi dönemde inşa etmektedirler. Cinsiyet tutumlarını üç yaşına geldiklerinde oyuncaklara yansıtmakta ve ebeveynlerinin cinsiyet ve oyun hakkındaki görüşlerini kolayca yansıtmaktadırlar (Burge, 1981). Okul öncesi dönemde her yaş grubundaki kız ve erkek çocuklar için kalıplaşmış oyuncak tercihleri ve bu oyuncak tercihindeki cinsiyet farklılıkları erken yaşlarda görülmektedir. Bu durum; biyolojik yatkınlıklar, bilişsel gelişim ve oyuncak tercihi üzerindeki çevresel etkiler bakımından tartışılmaktadır (Todd, Barry ve Thommessen, 2017). 3-6 yaş arasındaki çocuklarda oyuncak tercihinin; aile, arkadaş, renk, sosyal çevre etkisi gibi etmenlerden etkilendiği bilinmektedir. Ayrıca, erkek çocuklarının oyuncaklar konusunda görece kalıpyargısal ve cinsiyetçi tutum sergiledikleri; kız çocuklarının daha az cinsiyetçi tutuma sahip oldukları belirlenmiştir (Güder ve Albay, 2016). 1-5 yaş arası kız ve erkek çocuklarındaki cinsiyet özelliklerine ilişkin ön yargıların, erkek çocuklarda kız çocuklarına oranla biraz daha fazla olduğu belirlenmiştir (Kuzu, 2015).

Ebeveynlerin cinsiyet rol algıları ile çocuklarının seçtikleri oyun, oyuncak arasında ilişki olduğu saptanmıştır. Anne ve babanın ayrı ayrı cinsiyet rol algıları ile çocukların oyuncak tercihi arasındaki ilişki incelendiğinde; erkek çocukların kuvvet, hız, güç gerektiren oyunlardan yana tercihlerini kullandıkları, kız çocuklarının ise koruyan bakım veren ve grup içi etkileşim gerektiren oyunları tercih ettikleri sonucuna ulaşılmıştır. Anne dişil cinsiyet rol algısı ile kız çocukların peluş gibi oyuncaklarla oynaması arasında olumlu yönde bir ilişki bulunurken, annenin eril cinsiyet rol algısı ile erkek çocukların peluş tarzında oyuncak tercihleri arasında olumsuz bir ilişki saptanmıştır. Babanın 
dişil cinsiyet rol algısı ile erkek çocukların konuşmalarında saldırganca cümleler kullanma, alay etme gibi davranışlarda bulunma durumu arasında ilişki görülmektedir. Babanın eril cinsiyet rol algısı kız çocuklarının araba kullanma gibi aktiviteleri arasında negatif yönde bir ilişki saptanmıştır (Çiftçi ve Özgün, 2011). Okul öncesi dönemdeki çocukların toplumsal cinsiyet algılarını, ailenin içinde bulunduğu farklı sosyoekonomik düzeyden nasıl etkilenebileceği konusunda, anne babanın ev işleri konusunda paylaşımcı olmasının çocukları daha az kalıpyargısal yaptığı ortaya çıkmıştır. Baba baskısı hissedilmeyen, farklı cinsiyetten kardeşe sahip olan, farklı cinsiyete ait oyuncak sahibi olan çocukların oyuncaklar konusunda kalıp yargılarının azaldığı belirlenmiştir (Güder ve Yıldız, 2016). Ayrıca, okul öncesi dönem çocuklarının cinsiyete dayalı oyuncak seçimi, cinsiyetler arası davranış konusundaki yargıları ve cinsiyete bağlllık arasındaki ilişkileri incelendiğinde görülmektedir $\mathrm{ki}$, ahlaki ve sosyal normları ayırt edebilen daha esnek normlara sahip çocuklar, katı normlara sahip çocuklara göre daha az cinsiyet tipi oyuncak seçimleri sergilemişleridir (Lobel, v.d., 1993).

Annelerin cinsiyet rolleri ve çocuklarının oyuncak tercihi arasındaki ilişkiyi inceleyen bir çalışmada annelerin cinsiyet rolleri, feminen, maskülen ve androjen olarak sınıflandırmıştır. Androjen annelerin çocuklarının belirgin bir oyun ve oyuncak türünde yoğunlaşmadığı gözlenmiştir. Feminen annelerin kız çocuklarının oyuncak tercihi evcilik oyuncakları türünde iken, maskülen annelerin erkek çocuklarının taşıt türünde oyuncakları seçtikleri görülmüştür. Androjen annelerin çocukları aktif oyunlar, yap-inşa oyunları gibi farklı oyunları tercih ettiği tespit edilmiştir (Aksoy ve Baran, 2017). Bazı araştırmalara göre, annenin eğitim düzeyi yükseldikçe çocukların cinsiyete ilişkin kalıp yargıları da artmaktadır. Eğitim düzeyi arttıkça annelerin toplumsal dinamikleri daha iyi analiz ettiği ve çocukları üzerinde toplumsal cinsiyet konusunda da daha fazla kaygılandıkları ve bunun sonucunda önyargılarının pekiştiği sonucuna ulaşılabilir. Erkek çocukları kız çocuklarına kıyasla daha yüksek düzeyde kalıp yargılara sahiptir. Kız çocukları, bebek ve mutfak ile ilgili seçimler yaparken erkek çocuklarının, taşıt, tabanca gibi oyuncakları seçtiği gözlemlenmiştir (Kahraman ve Başal, 2011).

Babaların toplumsal cinsiyet konusunda sahip oldukları kalıp yargıların çocukların oyun ve oyuncak seçimini etkilediği görülmektedir. Özellikle er- 
kek çocuklar seçtikleri oyuncağın karşı cinsiyete uygun bir oyuncaksa babalarının bu duruma tepkisel yaklaşacağını düşünmektedirler (Raag ve Rackliff, 1998, s.698; Yağan ve Güler, 2016, s.439; Fagot ve Hagan, 1991).

Farlı sosyoekonomik düzeydeki anne ve babalar incelendiğinde, babaların sosyoekonomik düzeyi düştükçe eril cinsiyet rol algısının arttı̆ı görülmektedir. Sosyoekonomik düzey ebeveynlerin cinsiyet rol algiların etkilemekte, ebeveynler de çocukların oyuncak tercihini ve akran ilişkilerini etkilemektedirler (Aydilek ve Özgün, 2011, s.2259). Yüksek eğitim düzeyindeki ebeveynlerin oyuncak tercihinde ve satın almada cinsiyete dair kalıp yarg1lara önem vermedikleri gözlemlenmiştir. Bunun eğitim düzeyi ile ilgili olduğu düşünülmektedir (Güvenç ve Demircili, 2018). Çocukların oyuncak tercihleri konusunda literatürde çalışılmış 75 araştırmanın bulgularını değerlendirip analiz eden kapsamlı bir çalışmaya göre çıkan sonuç; çocukların cinsiyetlerine göre oyuncak tercih ettikleridir. Kızlar araştırmacıların nötr olarak sınıflandırdığı oyuncakları erkeklerden daha fazla tercih etmişlerdir (Davis ve Hines, 2020).

\section{Toplumsal Cinsiyet}

Cinsiyet kavramı, biyolojik ve toplumsal olarak iki farlı alanda tanımlanmakta ve nitelendirilmektedir. Biyolojik olarak kadın ya da erkek olarak dünyaya gelen insan zamanla, toplumsal olarak 'kadın' ve 'erkek' olma sürecine katılmaktadır. Konuya ilişkin 'Toplumsal cinsiyet' kavramı Ann Oakley tarafından 1972 yılında sosyoloji literatürüne kazandırılmıştır. Bu açıdan cinsiyet biyolojik olarak kadın, erkek gibi ayırt edici unsur olmakla beraber, toplumsal olarak da ayırt edici nitelikler arz etmektedir.

Toplumsal cinsiyetin inşasında tarihsel süreç incelendiğinde, kadın ve erkek arasındaki fizyolojik bazı farklılıkların önemli bir faktör olduğu yaygın görüşlerdendir. Doğum süreci, bebeğin bakımı gibi etkenler kadını daha çok ev ile ilgili işlere yöneltmektir. Günümüzde yaygınlaşan doğum kontrol, kadının üretim sürecine aktif katılımı gibi değişimlere rağmen kadının ev işleri ile rolünün pek fazla değişmediği görülmektedir. Toplumsal cinsiyet ve ev içi işbölümüne dair birçok araştırma, kadınların çalışma hayatında aktif olarak çalışsalar bile ev içindeki iş yüklerinin azalmadığını göstermektedir (Vatandaş, 2011). Kadının toplumda nezdinde konumlandırılışında; ev, ev işleri, 
çocuğun bakımı önemli bir yer tutmaktadır. Çalışan kadınlarda bile ev işlerinin yükümlülüğü ve çocukla ilgili işler, mevcut mesleğine ek olarak devam etmektedir. Erkeğin bu işlerden sorumluluğu görece daha az derecededir (Bingöl, 2014). Yani bu kavram sadece bireylerin kazandığ tan daha öte, yapısal düzeyde toplumsal yaşamdaki iş bölümü, sembolik düzeyde ise kadın ve erkek stereotipilerini içinde barındıracak kadar kapsamlı bir hale gelmiştir (Marshall, 1999, s.98).

Cinsiyete dair bu kalıp yargilar, sinema, televizyon dizileri, reklamlar gibi kitle iletişim araçları ile daha da pekiştirilmektedir. Çocuklar da bu kalıp yargıları gözlemleyerek ve model alarak bu toplumsal kalıp yargı zincirinin birer halkasını oluşturmaktadırlar. Reklamlarda anne edilgen bir figür olarak ev ile ilgili işlerde, baba aktif bir figür olarak çalışma hayatında gösterilmektedir. Kız çocukları için evcilik, bebek ve pembe renkler ile dolu bir dünya tasarlanırken, erkek çocukları için top oynadığı, daha aktif oyunlarda yer aldığı bir dünya tasarlanmaktadır. Böylece reklamlar aracilığıyla, cinsiyete dair kalıp yargılar hem inşa edilmekte hem de pekiştirilmektedir (Gündüz, 2010). Çocuklar bu kalıp yargilar konusunda, kendi cinsiyetinden olan ebeveyni ile kendini daha çok özdeşleştirerek model almaktadır. Cinsiyet rollerini bu taklit yolu ile inşa ederek oluşturmakta ve içselleştirmektedirler (Gündüz, 2010, s.87). Bu yönüyle aile, toplumsal cinsiyetin oluşturulduğu ve topluma nüfuz ettiği önemli ve temel kurumlardan biridir (Bingöl, 2014, s.108).

Toplumsal cinsiyet son yıllarda oldukça önem verilen ve somut olarak da ölçülmesi amaçlanan bir konudur. Dünya Ekonomik Forumunun farklı ülkeleri analiz ettiği Küresel Cinsiyet Eşitsizliği Endeksi bulunmaktadır. Bu endeks, kadınlara sağlanan eğitim olanakları, fırsat eşitliği, kadınların ekonomiye katılımı, sağlık ve siyasi alanda kadınların yeri gibi temel başlıklara göre hazırlanmaktadır. Ülkemiz, Dünya Ekonomik Forumu'nun 2020 Küresel Cinsiyet Eşitsizliği Endeksi'nde 153 ülke arasında 130. Sırada yer almıştır. Endekste Türkiye; kadınların ekonomiye katılımı ve fırsat eşitliği kategorisinde 136., işgücüne katılımda 135., aynı işe eşit ücrette 106., eğitim olanaklarına erişimde 13., sağlıkta 64. ve siyasi yaşamda temsilde 109. sırada yer almıştır. (We Forum, 2020). 


\section{Oyuncak Satın Alma Niyeti}

Cinsiyet kavramının toplumsal açıdan algılanışının, toplum nezdinde değerlendirilme biçiminin ebeveynlerin oyuncak tercihine yansıması kaçınılmazdır. Bu açıdan hem ebeveyn hem de çocuk bu durumdan bağımsız olarak düşünülemez. Çocukların oyuncak tercihinde; çocukların yaşları, cinsiyetleri, oyuncak reklamları, firmaların oyuncak tasarımları, oyuncağın rengi, aile, ebeveynin evdeki rolü, akran, sosyal çevre etkisi gibi faktörler oldukça etkili olarak görülmektedir. Çocuğun yaşı arttıkça cinsiyete dair kalıp yargıları da artmakta ve oyuncak tercihini bu doğrultuda yapmaktadır. Erkek çocukları, kız çocuklarına göre oyuncakları cinsiyete göre kategorileştirme eğiliminde olup, cinsiyete dair kalıp yargılara daha yüksek oranda sahiptir. Oyuncak reklamlarının ve firmaların ekonomik kaygılar güderek var olan toplumsal algiyı devam ettirerek kız oyuncağı, erkek oyuncağı ayrımı yapması da çocukların oyuncak tercihlerini etkilemektedir. Toplumsal algı oyuncaklara yansitılarak çocuklara sunulmaktadır (Güder ve Alabay, 2016, s.105-107). Son yıllarda, çizgi filmlerde ve animasyon filmlerde karakterlerin figürleri oyuncak olarak tasarlanarak çocuklara sunulmaktadır. Ayrıca, oyuncak firmaları ürün yerleştirme konusunda sinema ve televizyon sektörünü aktif şekilde kullanmaktadırlar. Çocuklar, ürün yerleştirme yapan bu markaları ve ürünlerini hatırlayarak, ebeveynleri üzerinde bu oyuncakları satın almaları konusunda etki oluşturmaktadırlar. Çoğu zaman bu etki sonucunda ebeveynin oyuncağı satın aldığı görülmektedir (Sarıyer ve Ayar, 2013, s.92-93).

Çocuğun tüketim sürecindeki serüveni yaş, bilişsel ve sosyal gelişimler ile üç evrede ele alınabilir. Algısal Evre (3-7 yaş), Analitik Evre ( 7-11 yaş), Düşünme Evresi( 11-16 yaş). Algısal evrede (3-7 yaş ), çocuk genel bir yönelim ile pazarın kolayca gözlemlenebilen genel özelliklerine odaklanabilir. Ürünleri nitelik bakımından ve sadece kendi basit gözlemleri ile değerlendirebilirler, basit ve sinırlı bir tüketici bilgisine sahiptirler sadece. Markayı tanıyabilirler ama sadece yüzeysel özelliklerinin farkındadırlar, örneğin semboller gibi. Bilgiyi kodlama, analiz etme gibi yetilere sahip olmadıkları için bireysel nesneler ya da deneyimler ile değerlendirmektedirler. Yani çocuk, kararları sınırlı bir alg1 ve bireysel değerlendirmeler ile almaktadır (John, 1999: 186187). Bu durum, çocuğa sunulan tanıtım faaliyetleri açısından oldukça önemlidir. Teknolojinin gelişmesi ile birlikte çocuklar da ürünler, markalar, rek- 
lamlar ile daha erken yaşta tanışmaktadırlar. Günümüzde çocuk, ailenin satın alma kararı üzerinde etkin bir hale gelmiştir. Aileler, çocukları satın alma sürecine müdahil ederek onların da fikirlerini almaya başlamıştır. Çocuğun seçim ve beğenileri, ailenin satın alma kararında reklam gibi pazarlama stratejilerinden daha etkili olmaktadır. Bu yönüyle çocuklar, markalar için önemli bir tüketici kitlesidir ve pazarlama stratejileri bakımından dikkate allnan önemli bir kitle durumundadır (Gülarslan, 2013, s.135-136).

\section{Araştırmanın Yöntemi}

Bu bölümde, araştırmada izlenecek yöntem ve model belirtilerek, araştırmanın evren ve örneklemi/araştırma grubu hakkında bilgi verilecektir. Ayrıca araştırma verilerinin nasıl toplanacağı, planlanan veri toplama araçlarl, veri toplama/işlem sürecine ilişkin açıklamalarla birlikte, verilerin nasıl analiz edileceği kısaca belirtilecektir.

\section{Araştırmanın Ana Kütlesi ve Örneklemi}

Araştırmanın kapsamını, 0-6 yaş aralığında çocuklar ve onların ebeveynleri oluşturmaktadır. Çocukların, oyuncaklara yönelik cinsiyet tutumlarını, bu yaş aralığında daha belirgin şekilde yansıttıkları da bilinmektedir. Bu çalışmada, sadece ebeveynlerin tutumları incelenmeye çalışıldığından çocukların yaş aralığ $10-6$ olarak belirlenmiştir.

Örneklem, \%95 Güven aralığında ve 0,05 hata payı ile hesaplanarak Kırşehir için 374 bulunmuştur (Nakip, 2013, s.292). Anket sayıları, Kırşehir ilinde yaşayan 0-6 yaş aralığında çocukların sayısı ve onların ebeveynleri göz önüne alınarak oransal olarak belirlenmiştir.

\section{Araştırmanın Veri Toplama Araçlarn}

Araştırmada verilerin toplanmasında online anket metodu kullanılmıştır. Anketler, belirlenen örneklem metoduna göre uygulanmıştır. Literatürde yer alan iki adet ölçekten faydalanılmıştır. Ölçekler; Cinsiyet rolleri tutum ölçeği (Burge'den uyarlama 1981), Satın alma niyeti ölçeği (Duffett, 2015). Cinsiyet rolleri tutum ölçeği (Burge' den uyarlama 1981) toplamda 19 maddelik bir ölçektir. Bu ölçek, ebeveynlerin cinsiyete özgü oyuncak seçimleri ve cinsiyete özgü davranışlarla ilgili tercihlerini açıklamak için geliştirilmiştir. Satın alma 
niyeti ölçeği, Duffett (2015) tarafından geliştirilmiş olup toplamda 9 maddeden oluşmaktadır ve bu çalışmada ebeveynlerin cinsiyete özgü oyuncak satın alma niyetini ölçmektedir. Anketin demografik bölümünde ebeveynlerin oyuncak satın alırken çocuklarının seçmesine izin verme durumu ve ebeveynlerin satın aldıkları oyuncakları çocukları ile birlikte oynama durumu ile ilgili ek sorular sorulmuştur. Ankette kullanılacak olan ölçeklerin orijinalleri, İngilizcedir. Dolayısı ile Türkçeye tercümesi yapılarak uygulanmıştır. Anket, Aralık 2019 - Şubat 2020 tarihleri arasında devamlı uygulanmıştır.

Anket uygulaması sonucunda toplamda 602 anket elde edilmiştir. Fakat, anket formunun yanlış ya da eksik doldurulması, sorulardaki içeriklerin dikkatli okunmaması sonucunda bazı anketler elenerek sonuç itibariyle, kullanılabilir 531 adet anket verisine ulaşılmıştır.

\section{Bulgular}

\section{Katılımcılarn Demografik Özellikleri}

Tablo 1. Araştırmaya katılan ebeveynlerin demografik özelliklerine ilişkin bulgular

\begin{tabular}{|c|c|c|c|c|c|}
\hline Cinsiyet & $\mathbf{F}$ & $\%$ & Meslek & $\mathbf{F}$ & $\%$ \\
\hline Kadın & 437 & 82,3 & Kamu Çalışanı & 200 & 37,7 \\
\hline Erkek & 94 & 17,7 & Özel Sektör & 128 & 24,1 \\
\hline Toplam & 531 & 100,0 & Emekli & 160 & 30,1 \\
\hline Aylık Gelir & $\mathbf{F}$ & $\%$ & Çalışmıyor & 43 & 8,1 \\
\hline 2499 ve altı & 37 & 7,0 & Toplam & 531 & 100,0 \\
\hline $2500-4000$ & 103 & 19,4 & \multicolumn{2}{|l|}{ Ebeveynlerin Satın Aldıkları OyuncaklarıF } & $\%$ \\
\hline $4001-5500$ & 102 & 19,2 & \multicolumn{2}{|l|}{ Çocukları İle Birlikte Oynama Durumu } & \\
\hline $5501-7000$ & 98 & 18,5 & Her Zaman & 331 & 62,3 \\
\hline 7001 ve üzeri & 191 & 36,0 & Bazen & 197 & 37,1 \\
\hline Toplam & 531 & 100,0 & Hiçbir Zaman & 3 & 6 \\
\hline Çocukların Cinsiyeti & $\mathrm{F}$ & $\%$ & Toplam & 531 & 100,0 \\
\hline Kiz & 258 & 48,6 & \multicolumn{2}{|l|}{ Ebeveynlerin Oyuncak Satın Alırken Ço-F } & $\%$ \\
\hline Erkek & 249 & 46,9 & \multicolumn{2}{|l|}{ cuklarının Seçmesine İzin Verme Durumu } & \\
\hline Kiz ve Erkek & 24 & 4,5 & Her Zaman & 238 & 44,8 \\
\hline Toplam & 531 & 100,0 & Bazen & 286 & 53,9 \\
\hline Eğitim Durumu & $\mathbf{F}$ & $\%$ & Hiçbir Zaman & 7 & 1,3 \\
\hline İlköğretim & 15 & 2,8 & Toplam & 531 & 100,0 \\
\hline Lise & 98 & 18,5 & Yaş & $\mathbf{F}$ & $\%$ \\
\hline Lisans & 308 & 58,0 & $18-29$ & 87 & 16,4 \\
\hline Lisansüstü & 110 & 20,7 & $30-35$ & 289 & 54,4 \\
\hline \multirow[t]{3}{*}{ Toplam } & 531 & 100,0 & $36-39$ & 105 & 19,8 \\
\hline & & & 40 ve üzeri & 50 & 9,4 \\
\hline & & & Toplam & 531 & 100,0 \\
\hline
\end{tabular}


Analiz sonuçlarına göre; katılımciların \%82,3'ü kadın, \%17,7'si erkek, \%36'lık kesimin 7001 TL ve üzeri, \%19,4'lük kesimin 2500-4000 TL aralığında, $\% 19,2^{\prime}$ lik kesimin ise 4001-5500 TL aralığında gelir düzeyinde oluğu, \%58' lik kesimin lisans, \%20,7'lik kesimin lisansüstü, \%18,5'lik kesimin ise lise mezunu olduğu, \%37,7'lik kesimin kamu sektörü çalışanı, \%30,1'lik kesimin emekli, \%24,1'lik kesimin ise özel sektör çalışanı olduğu, \%54,4'lük kesimin 30-35 yaş aralığında, \%19,8'lik kesimin 36-39 yaş aralığında, \%16,4'lük kesimin ise 18-29 yaş aralığında olduğu görülmektedir. Katılımcıların çocuklarının \%48,6'sı kız, \%46,9'u erkektir. \%62,3'ü satın aldıkları oyuncakları çocukları ile her zaman birlikte oynarken, \%37,1'i ise satın aldıkları oyuncakları çocukları ile bazen oynamaktadır. Katılımcların $\% 53,9^{\prime}$ u oyuncak satın alırken çocuklarının seçmesine bazen izin verirken, $\% 44,8$ 'i çocuklarının oyuncaklarını seçmesine her zaman izin vermektedir.

Tablo 2. Normal Dağılım ve Güvenilirlik analizi sonuçları

\begin{tabular}{ll}
\hline Ölçekler & Güvenilirlik \\
Cinsiyet Rolleri Tutum Ölçeği & 0,749 \\
Satın Alma Niyeti Ölçeği & 0,833 \\
\hline
\end{tabular}

Güvenilirlik analizinde Cronbach's Alpha katsayısı kullanılmıştır. Güvenilirlik analizi sonucunda elde edilen Cronbach's Alpha değerleri Cinsiyet rolleri tutum ölçeği için 0,749 satın alma niyeti ölçeği için 0,833 değerinde bulunmuştur.

Tablo 3. Normal Dağılım ve Güvenilirlik analizi sonuçlan

\begin{tabular}{lll}
\hline Ölçekler & Basıklık & Çarpıklık \\
Cinsiyet Rolleri Tutum Ölçeği &,- 197 &,- 075 \\
Satın Alma Niyeti Ölçeği &,- 817 &, 141 \\
\hline
\end{tabular}

Nicel bir araştırmada, parametrik testlerin yapılabilmesi için elde edilen verilerin dağılımının normal dağılması gerekmektedir. Yapılan analizde, çarpıklık ve basıklık değerleri -2.0 ve +2.0 arasında olduğu görülmektedir. $\mathrm{Bu}$ veriden hareketle verilerin normal dağıldığı saptanmış ve parametrik testlerin uygulanması aşamasına geçilmiştir. 
Tablo 4. Pearson Korelasyonu Tablosu

\begin{tabular}{lll}
\hline & & Satın Alma Niyeti \\
Ebeveynlerin Oyuncak Seçiminde Cinsiyet Algısı & Pearson Korelasyon & 0,378 \\
& $\mathrm{P}$ & 0,000 \\
\hline
\end{tabular}

Tablo 4.'de pearson korelasyon analizi incelendiğinde, ebeveynlerin oyuncak seçiminde cinsiyet algısı ile satın alma niyeti arasındaki korelasyon katsayıları görülmektedir. Yapılan analiz sonucunda, ebeveynlerin oyuncak seçiminde cinsiyet algısı ile satın alma niyeti arasındaki korelasyon katsayılarını $p=0,01$ düzeyinde pozitif ve anlamlı olduğu görülmektedir. Ebeveynlerin oyuncak seçiminde cinsiyet algısı ile satın alma niyeti arasında $(0,378)$ orta düzeyde bir ilişki olduğu tespit edilmiştir.

Tablo 5. Oyuncak Seçiminde Ebeveynlerin Cinsiyet Algısının Satın Alma Niyeti Üzerinde Etkisine İlişkin Regresyon Analizi Sonuçlar

\begin{tabular}{|c|c|c|c|c|c|c|c|c|}
\hline \multicolumn{3}{|l|}{ Bağımlı Değişken } & \multicolumn{6}{|c|}{ Satın Alma Niyeti } \\
\hline \multirow{2}{*}{ Değişkenler } & \multicolumn{2}{|c|}{ Katsayılar } & \multicolumn{2}{|c|}{ Anlamlılık Derecesi } & \multirow{2}{*}{$\mathrm{R}^{2}$} & \multirow{2}{*}{$\begin{array}{l}\text { Düzeltilmiş } \\
\mathrm{R}^{2}\end{array}$} & \multirow{2}{*}{$\mathrm{F}$} & \multirow{2}{*}{$\mathrm{P}$} \\
\hline & $\mathrm{B}$ & Beta & $\mathrm{t}$ & $P$ & & & & \\
\hline Sabit & 1,593 & & 9,170 & 0,000 & 0,143 & 0,141 & & \\
\hline Oyuncak Seçiminde Cinsiyet Algısı & 649 & ,378 & 9,392 & 0,000 & & & 88,216 & 0,000 \\
\hline
\end{tabular}

Tablo 5. incelendiğinde $\% 5$ anlamlılık düzeyinde $p$ değeri 0,000 olduğundan modelin genel olarak anlamlı olduğu, bağımsız değişken oyuncak seçiminde cinsiyet algısının p değerinin $(0,000) 0,05$ 'ten küçük olduğu görülmektedir ve katsayıları istatistik olarak anlamlıdır. Bu durumda $\mathbf{H}_{1}$ hipotezi kabul edilmiştir.

$\mathrm{R}^{2}$ değeri bağımlı değişkendeki değişimlerin ne kadarının bağımsız değişken tarafından açıklandığını göstermektedir (İslamoğlu ve Alnıaçı. 2019: 380). Yani satın alma niyetindeki $\% 14,3^{\prime} l u ̈ k ~\left(R^{2}=0,143\right)$ değişimin oyuncak seçiminde cinsiyet algısına bağlı olduğu söylenebilir.

Ebeveynlerin oyuncak seçiminde cinsiyet algısındaki bir birimlik artış satın alma niyetini 0,378 birim arttırmaktadır. Buna göre ebeveynlerin oyuncak seçiminde cinsiyet algısının satın alma niyeti üzerinde orta düzeyde bir etkisinin olduğu, ebeveynlerin oyuncak seçiminde cinsiyet algısının arttıkça satın alma niyetinin de arttığı sonucuna ulaşılmıştır. 
Tablo 6. Cinsiyete göre T-testi tablosu

\begin{tabular}{llllllll}
\hline \multirow{2}{*}{ Faktörler } & Cinsiyet & $\mathbf{N}$ & Ortalama & SS & T & Sd & P \\
& & & & & & & \\
\hline \multirow{2}{*}{ Oyuncak Seçiminde Cinsiyet Algısı } & Kadın & 437 & 2,4121 &, 47886 & $-5,200$ & 529 & 0,000 \\
\cline { 2 - 7 } Satın Alma Niyeti & Erkek & 94 & 2,6993 &, 51693 & & & \\
\cline { 2 - 7 } & Kadın & 437 & 3,2438 &, 87308 & 529 & 0,003 \\
\hline
\end{tabular}

Tablo 6.'da t testi sonucu elde edilen $p$ değerleri incelendiğinde, oyuncak seçiminde cinsiyet algısının p değeri 0,05 anlamlılık değerinden küçük olduğu için katılımcıların cinsiyetlerine göre anlamlı farklılık gösterdiği belirlenmiştir. Grup ortalamalarına göre erkek katılımcların kadın katılımcılara göre oyuncak seçiminde cinsiyet algılarının daha yüksek olduğu söylenebilir. Bu durumda $\mathbf{H}_{2 a}$ hipotezi kabul edilmiştir. Yani ebeveynlerin oyuncak seçiminde cinsiyet algıları cinsiyetlerine göre anlamlı farklılık göstermektedir.

Satın alma niyeti ölçeğinin $p$ değeri 0,05 anlamlılık değerinden küçük olduğu için katılımcıların cinsiyetlerine göre anlamlı farklılık gösterdiği görülmektedir. Grup ortalamalarına göre kadın katılımcların erkek katılımcılara göre satın alma niyetlerinin daha yüksek olduğu söylenebilir. Bu durumda $\mathbf{H}_{3 \mathbf{a}}$ hipotezi kabul edilmiştir.

Tablo 6. Eğitim Durumuna Göre ANOVA Tablosu

\begin{tabular}{llllllll}
\hline Faktörler & Eğitim Durumu & $\mathbf{N}$ & Ortalama & SS & F & P & $\begin{array}{c}\text { Anlaml } \\
\text { Farklılık }\end{array}$ \\
Oyuncak Seçiminde & İlköğretim & 15 & 2,3754 &, 66272 & & & \\
Cinsiyet Algısı & Lise & 98 & 2,5161 &, 54480 & \multirow{2}{*}{, 939} & 0,421 & \\
& Lisans & 308 & 2,4385 &, 48651 & & & \\
& Lisansüstü & 110 & 2,4962 &, 45841 & & & \\
& İlköğretim & 15 & 2,7556 &, 95876 & & & \\
\multirow{2}{*}{ Satın Alma Niyeti } & Lise & 98 & 3,0147 &, 98009 & & & \\
& Lisans & 308 & 3,1966 &, 84726 & 4,972 & 0,002 & $2-4$ \\
\hline
\end{tabular}

Tablo 6 incelendiğinde, satın alma niyeti ölçeğinin p değeri 0,05 anlamlılık değerinden küçük olduğu için ebeveynlerin eğitim durumlarına göre anlamlı farklılık gösterdiği tespit edilmiştir. Eğitim durumuna göre yapılan ANOVA testinde verilerin homojen dağılım göstermemesi nedeni ile gruplar arası farklılıkların belirlenmesinde Post Hoc testlerinden Games-Howell testi kullanılmıştır. Tablo 4.10. incelendiğinde lise ve lisansüstü eğitim durumları ara- 
sinda anlamlı farklılık olduğu görülmektedir. Genel olarak grup ortalamalarına göre bireylerin eğitim düzeyleri arttıkça satın alma niyetlerinin de arttığ1 görülmektedir.

\section{Sonuç ve Tartışma}

$\mathrm{Bu}$ araştırmada, ebeveynlerin toplumsal cinsiyet rolleri tutumları ve algiları ölçülerek bu tutum ve algıları sonucunda oyuncak satın alma niyetleri analiz edilmiştir. Ebeveynlere, kız ve/veya erkek çocuklarının toplumsal cinsiyet rolleri, davranışları, oyuncakları, ilgi alanları, mizaçları, duyguları gibi içerikler açısından farklı olup olmaması gerektiğine dair sorular yöneltilmiştir. "Oğluma bir bebek alabilirim.", "Kızım, küçükler liginde futbol oynamak isterse üzülürüm.”, “Oğluma ve kızıma aynı tür oyuncakları alırım.”, "Ebeveynler, kız ve erkek çocuklar için farklı davranış standartları belirlemelidir." ankette yer alan bu gibi sorularla ebeveynlerin cinsiyet rolleri konusunda tutumları ölçülmüştür. Ebeveynlerin kız/erkek oyuncağı ayrımı olmayan oyuncaklar satın alma niyetleri de belirlenerek kapsamlı bir analiz yapılmıştır.

Araştırma sonucunda, oyuncak seçiminde ebeveynlerin cinsiyet rolleri tutumlarının satın alma niyetleri üzerinde etkisi olduğu belirlenmiştir. Yani cinsiyet konusunda ayrıştırıc bir anlayış geliştirmeyerek kız ve erkek çocuklarının benzer oyuncaklarla oynaması gerektiği algısına sahip ebeveynlerin, cinsiyet konusunda farklılaştııılmamış oyuncak satın alma eğiliminde oldukları söylenebilmektedir. Cinsiyet rolleri konusunda bu tutum, satın alma niyetlerini de doğrudan etkilemektedir.

Ebeveynlerin oyuncak seçiminde cinsiyet algıları demografik özelliklerine göre anlamlı farklılık göstermektedir. Erkek katılımcıların kadın katılımcılara göre cinsiyet rolleri tutumu daha yüksek oranda görülmüştür. Yani baba, anneye göre daha az cinsiyetçi yaklaşım göstermektedir. Bu sonuç anketi cevaplayan erkek katılımcıların eğitim düzeyi ile birlikte değerlendirildiğinde olası olarak görülmektedir. Ebeveynlerin satın alma niyetlerinin demografik özelliklerine ve eğitim durumlarına göre anlamlı farklılık gösterdiği belirlenmiştir. Bireylerin eğitim düzeyi arttıkça cinsiyete göre farklılaştırılmamış olan oyuncakları satın alma niyetleri de artmaktadır. Ayrıca kadın katılımciların erkek katılımcılara göre satın alma eğilimi görece yüksektir. Yani anne babaya göre daha fazla satın alma eğilimindedir. Ebeveynlerin \%62,3'ü satın aldıkları oyuncakları çocukları ile "her zaman" birlikte oynarken, \%37,1'i ise 
satın aldıkları oyuncakları çocukları ile "bazen" oynamaktadır. "Hiçbir zaman" seçeneğini işaretleyen ebeveyn neredeyse yoktur. Bu bilgiden hareketle, ebeveynlerin çocukları ile oyun oynama konusunda paylaşım içinde oldukları yorumu yapılabilir. Ebeveynlerin $\% 53,9^{\prime}$ u oyuncak satın alırken çocuklarının seçmesine "bazen" izin verirken, $\% 44,8$ 'i çocuklarının oyuncaklarını seçmesine "her zaman" izin vermektedir. Cevaplarda çocuğunun oyuncak seçmesine hiçbir zaman izin vermeyen ebeveyne neredeyse rastlanmamıştır. Çocukların oyuncak satın alma sürecinde fikirlerinin alındığı ve sürece müdahil oldukları yorumu yapılabilir

Son yıllarda toplumsal cinsiyet algısı değişkenlik göstererek, kadın ve erkek rollerini keskin hatlarla birbirinden ayırmak yerine daha fazla ortak paydada buluşturmuştur. Bu noktada oyuncak markaları oyuncaklarda renk, şekil gibi cinsiyet göstergeleri kullanmak yerine daha nötr oyuncaklar üreterek ebeveynlerin değişen taleplerini karşılayabilirler. Androjen olarak nitelendirilen ebeveynlerin çocuklarına yönelik olarak nötr oyuncak kategorisi oluşturabilirler.

Üretim ve tanıtım aşamasında oyuncakları türleri bakımından kategorize etmeyerek üretip sunabilirler. Örneğin tamir setini mavi renk üretmeyip, erkek çocuğu oyuncakları reyonunda sergilememek. Bebekleri, mutfak setlerini pembe renkte üretmeyip kız çocukları reyonunda sergilememek gibi...

Oyuncak markaları, reklamlarında ve diğer tüm tanıtım faaliyetlerinde kız ve erkek çocuklarını toplumsal cinsiyet açısından ayrıştırmadan konumlandırabilirler. Reklamlarında anne ve baba figürünü toplumsal cinsiyet açsından farklılaştırmayıp, anneyi edilgen babayı ise etken bir figür olarak göstermeden konumlandırabilirler.

Oyuncak markaları oyuncak tasarım aşamasında çeşitli anketler uygulayarak ebeveynlerin sürece müdahil olmasını sağlayabilirler.

Literatür incelemesi sonucunda görülmektedir ki, toplumsal cinsiyet ve oyuncak konusunda yapılan çalışmalar çoğunlukla sadece nicel ya da sadece nitel araştırma yöntemi ile yapılmıştır. Karma yöntem kullanılarak yapılan araştırma görece az sayıdadır. Araştırmalarda çoğunlukla çocuklar katılımcı olarak örnekleme dahi edilirken, ebeveynler ve eğitimciler üzerinde çok fazla çalışılmadığı görülmüştür. Bu araştırmada örneklem olarak ebeveynler seçilmiş ve sahip oldukları toplumsal cinsiyet algısının oyuncak satın alma niyetlerine yansıması incelenmiştir. Bu açıdan literatüre katkı sağlayacak nitelikte olduğu düşünülmektedir. 
Araştırmanın nicel araştırma metodu kullanılarak sadece anket yöntemiyle gerçekleştirilmesi, katılımcıların ifadelere doğru yanıtlar verdiğinin varsayılmasını gerektirmekte ve araştırma sonuçlarının mutlak kesin sonuçlar olarak değerlendirilmesini engellemektedir. Bu bakımdan araştırma nitel araştırma metodu ile zenginleştirilirse karma bir yöntem ile daha açıklayıcı ve sağlıklı sonuçlara ulaşılabilir. Bu bakımdan bu durum araştırmanın kısıtını oluşturmaktadır. Bu çalışma aynı isimli yüksek lisans tezinden üretilmiştir. Tez karma bir yöntemle yapılmaktadır ve nitel araştırma kısmının veri analizi devam etmektedir. Nitel kısım için ebeveynlerle yarı yapılandırılmış görüşme tekniği ile veriler toplanmış ve analiz sürecine dahil edilmiştir. Tüm analizler tamamlandığında daha açıklayıcı ve kapsamlı sonuçlara ulaşılacağı öngörülmektedir. 


\title{
EXTENDED ABSTRACT
}

\section{The Effect of Parents' Gender Perception In Toy Selection On Purchasing Choices}

\author{
Deniz Akgül - Öznur Özer \\ Kırşehir Ahi Evran Üniversitesi
}

The toy, which is the main tool of the game, is an object of the game, but it is an important tool for children that develops their imaginary world, acquires several motor skills, contributes mentally and socially. Games and toys are important educators in the physical, emotional, mental, and social development of the child. Preschool is a critical and very important stage in shaping the child's perspective on life and internalizing gender roles by positioning them in their mind. At this stage, the game and toy have a significant effect, such as the bridge between the child and the world. In this aspect, games, and toys for the child are like a rehearsal of life. By building a miniature version of the real world with the game, it creates its reality in a small space. In this area, s/he also positions him(her)self, mowing roles and gaining his/her identity.

Young children build their understanding of gender in preschool. They reflect their gender attitudes to toys by the time they turn three and easily reflect their parents' views on gender and games (Burge, 1981). Stereotypical toy preferences for girls and boys in all age groups in the preschool period and gender differences in this toy preference are observed at an early age. This is discussed in terms of environmental effects on biological predispositions, cognitive development, and toy preference (Todd, Barry, and Thommessen, 2017). It is known that toy preference in children between the ages of 3-6 is affected by factors such as family, friends, color or social environment. Besides, it was determined that boys have a relatively stereotypical and sexist attitude toward toys; girls have a less sexist attitude (Güder and Albay, 2016). It was determined that prejudices regarding gender characteristics in girls and boys aged 1-5 years were slightly higher in boys than in girls (Kuzu, 2015). 
A study of mothers and fathers at different socioeconomic levels shows that as the socioeconomic level of fathers decreases, the perception of masculine gender roles increases. Socioeconomic levels influence parents' perceptions of gender roles, and parents also influence children's toy preferences and peer relationships (Aydilek and Özgün, 2011, p.2259). It has been observed that parents at a higher educational level do not care about gender stereotypes in toy preference and purchase. It is believed that this is related to the level of Education (Güvenç and Demircili, 2018). According to a comprehensive study that evaluated and analyzed the findings of 75 studies studied in the literature on children's toy preferences, the result is that children prefer toys according to their gender. Girls preferred toys that the researchers classified as neutral more than boys (Davis and Hines, 2020).

This study aims to investigate the effects of gender perception on toy purchases that parents make for their children. In toys, it is aimed to measure the gender indicators, such as the color shape that firms use, the attitudes of parents as consumers, and the effects of these attitudes on the decision to buy. The sexist attitudes of parents regarding toy shopping for their children were evaluated and the reflection of these attitudes on their consumption was examined. The basic purpose is to examine the attitudes of families during shopping and the variables that affect these attitudes towards gender indicators such as color, a shape that companies use in toys. At the same time, it is aimed to analyze by determining the variability of sexist attitudes according to the socio-cultural, socio-economic status of parents.

An online survey method was used to collect data in the research. Two scales have been used in the literature. Scales that have been used are gender roles attitude scale (adapted from Burge 1981) and purchase intention scale (Duffett, R. 2015). The gender roles attitude scale (adapted from Burge 1981) is a total of 19 items. This scale was developed to explain parents' preferences regarding gender-specific toy choices and gender-specific behaviors. The intention to buy scale was developed by Duffett (2015) and consists of a total of 9 items, and this study measures parents' intention to buy gender-specific toys. In the demographic section of the survey, additional questions were asked about the status of parents allowing their children to choose when buying toys, and the status of parents playing with their children on the toys they buy. 
As a result of the research, it was determined that parents' attitudes to gender roles in toy selection had an impact on their purchasing intentions. In other words, it can be said that parents who have the perception that girls and boys should play with similar toys, without developing a discriminatory understanding of gender, tend to buy toys that are not differentiated about gender. This attitude to gender roles also directly affects purchasing intentions.

Gender perceptions of parents' choice of toys differ significantly according to their demographics. Male participants had a higher rate of attitude to gender roles than female participants. So, the father shows a less sexist approach than the mother. This result is seen as possible when evaluated together with the level of education of the male participants who answered the questionnaire. It was determined that parents' purchasing intentions differ significantly according to their demographics and educational status. As individuals' educational level increases, their intention to buy toys that are not differentiated by gender also increases. Besides, female participants have a relatively high tendency to buy compared to male participants. So, parents tend to buy more than they do. $62.3 \%$ of parents play with the toys they buy "always" with their children, while $37.1 \%$ play with the toys they buy "sometimes" with their children. There are almost no parents who check the" Never " option. Based on this information, it can be interpreted that parents share playing games with their children. 53.9\% of parents "sometimes" allow their children to choose when buying toys, while $44.8 \%$ "always" allow their children to choose their toys. In the answers, there was almost no parent who never allowed their child to choose toys. It can be interpreted that children's ideas are taken and involved in the process of buying toys.

\section{Kaynakça / References}

Aksoy, P. ve Baran, G. (2017). Annelerin cinsiyet rollerine ilişkin özellikleri ile çocuklarin oyuncak tercihleri ve oynadiklari oyun türleri arasindaki ilişki üzerine bir çalişma. Eğitimde Nitel Araştırmalar Dergisi , 5 (1) , 102-136. 
Aydilek-Çiftçi, M ve Özgün, Ö. (2011) Okul öncesi dönemdeki çocuklarin oyuncak tercihlerinin ve akran etkileşimlerinin ebeveyn cinsiyet rolleri algisı bağlaminda incelenmesi, E-Journal Of New World Sciences Academy 6(3), Article Number: $1 \mathrm{c} 0438$.

Bingöl, O. (2014). Toplumsal cinsiyet olgusu ve Türkiye'de kadınlı. Karamanoğlu Mehmetbey Üniversitesi Sosyal Ve Ekonomik Araştrmalar Dergisi, 3 , 108-114 .

Çiftçi, M. (2011). Öğretmenlerin ve farklı sosyo-ekonomik düzeye sahip anne-babalarn cinsiyet rolleri algisinn 60-72 ay arast çocuklarm oyuncak tercihleri ve akran etkileşimleri ile ilişkisinin incelenmesi. Yayınlanmamış Yüksek Lisans Tezi). Çukurova Üniversitesi / Sosyal Bilimler Enstitüsü, Adana.

Davis, J.T.M., Hines, M. (t.y). How large are gender differences in toy preferences? A systematic review and meta-analysis of toy preference research. Archives of Sexual Behavior, 49, 373-394

Duffett, R. (2015). "Facebook advertising's influence on intention-to-purchase and purchase amongst millennials", Internet Research, 25(4), 498-526.

Fagot B.I. ve Hagan R. (1991) Observations of parent reactions to sex-stereotyped behaviors: age and sex effects. Child Dev. 62(3), 617-28. doi: 10.1111/j.14678624.1991.tb01556.x. PMID: 1914629.

Freeman, N. K. (2007). Preschoolers' perceptions of gender appropriate toys and their parents' beliefs about genderized behaviors: Miscommunication, mixed messages, or hidden truths?. Early Childhood Education Journal, 34(5), 357-366.

Güder: (2014). Okul öncesi dönemdeki çocuklarm toplumsal cinsiyet alglarmin incelenmesi.Yayınlanmamış doktora tezi). Hacettepe Üniversitesi Eğitim Bilimleri Enstitüsü, Ankara.

Güder: Y. ve Alabay, E. (2016). 3-6 yaş arasındaki çocukların oyuncak tercihlerinin toplumsal cinsiyet bağlamında incelenmesi. Ahi Evran Üniversitesi Kirşehir Eğitim Fakültesi Dergisi, 17( 2), 91-111.

Gündüz Kalan, Ö . (2010). Reklamda çocuğun toplumsal cinsiyet teorisi bağlaminda konumlandirilişi: 'Kinder' reklam filmleri üzerine bir inceleme. İstanbul Üniversitesi İletişim Fakültesi Dergisi, 1 (38) , 75-89.

Güvenç, D. ve Demircili, E. (2018). Oyuncakların pazarlanmasında toplumsal cinsiyet. Sosyal ve Beşeri Bilimler Dergisi, 10(1),1-17.

John D. R (1999) Consumer socializastion of children: A retrospective look at twenty - five years research, Journal of Consumer Research, 26 (3), 183 -213.

Kahraman, P.B. ve Başal, H.A. (2011). Anne eğitim düzeyine göre çocukların cinsiyet kalıpyargiları ile oyun ve oyuncak tercihleri. E-Journal of New World Sciences Academy Education Sciences. 6 (1),1344-1366. 
Kuzu, Ç. (2015). Okul öncesi dönemdeki çocuklarin cinsiyet önyargilari ile oyuncak seçimi ve ebeveynlerin buna etkisi. Uluslararası Sosyal Araştırmalar Dergisi 8(39), 2246-2261.

Lee Burge, P. (1981). Parental child-rearing sex-role attitudes related to social issue sex-role attitudes and selected demographic variables. Home Economics Research Journal, 9(3), 193-199.

Lobel, T. E., ve Menashri, J. (1993). Relations of conceptions of gender-role transgressions and gender constancy to gender-typed toy preferences. Developmental Psychology, 29(1), 150-155.

Marshall, G. (1999). Sosyoloji sözlü̈̆ü (O. Akınhay ve D. Kömürcü, Trans.): Bilim ve Sanat Yayınları.

Nakip, M. (2013) Pazarlama Araştırma Teknikleri, 3. Baskı, Ankara: Seçkin Yayınclık.

Nakipan, A . (2013). Tüketici olarak çocuk ve ailenin satın alma kararlarına etkisi. Selçuk Illetişim , 6 (4) , 126-137.

Raag, T., ve Rackliff, C. L. (1998). Preschoolers' awareness of social expectations of gender: Relationships to toy choices. Sex Roles 38(9-10), 685-700.

Sarıyer, N. ve Ayar, H. (2013). Filmlere yerleştirilen markaların çocuklar tarafindan hatirlanmasi - Toy Story III filmi örneği. Afyon Kocatepe Üniversitesi İktisadi ve İdari Bilimler Fakültesi Dergisi , 15 (1) , 79-99.

The World Economic Forum, (2020). Küresel cinsiyet eşitsizliği endeksi verileri. 2.3.2020 tarihinde http://www3.weforum.org/docs/WEF_GGGR 2020.pdf adresinden erişilmiştir.

Todd, B., Barry, J.A. ve Thommessen: (2017). Preferences for 'gender-typed' toys in boys and girls aged 9 to 32 months. Infant and Child Development, 26(3), e1986.

Vatandaş, D. (2011). Toplumsal cinsiyet ve cinsiyet rollerinin algilanışı. Istanbul Journal Of Sociological Studies , 35, 29-56.

Yağan G. ve Güler Yıldız, T. (2016). Okul öncesi dönemdeki çocukların toplumsal cinsiyet algilarında ailenin rolü. Hacettepe Üniversitesi Eğitim Fakültesi Dergisi, 31(2), 424-446.

Yağan-G. ve Güler-Yıldız, T. (2016). Okul öncesi dönemdeki çocukların toplumsal cinsiyet algilarında ailenin rolü. Hacettepe Üniversitesi Ë̆itim Fakültesi Dergisi (H. U. Journal of Education) 31(2), 424-446. 


\section{Kaynakça Bilgisi / Citation Information}

Akgül, D. ve Özer, Ö. (2020). Oyuncak seçiminde ebeveynlerin cinsiyet algisının satın alma niyeti üzerindeki etkisi. OPUS-Uluslararası Toplum Araştırmaları Dergisi, 17(38), 5332-5353. DOI: 10.26466/opus.891026. 